\title{
Characteristic Mycelial Phenotype of New Pleurotus spp. used as a Marker for Identification
}

\author{
S. Samundeeswari*, S. Viruthambigai, R. Kannan, \\ K. G. Sabarinathan and V. Ramamoorthy \\ Department of Plant Pathology, Agricultural College and Research Institute, \\ Killikulam, Vallanadu, Tamil Nadu, India \\ *Corresponding author
}

\section{A B S T R A C T}

\section{Keywords}

Pleurotus spp,

Phenotypic

characters, mycelium

\section{Article Info}

Accepted:

05 June 2020

Available Online:

10 July 2020
The present study was carried out to characterize two newly collected Pleurotus species viz., Pleurotus djamor isolate virutha1 and Pleurotus djamor isolate woody 1 compared with Pleurotus florida which is a commercial cultivar. All these Pleurotus spp. grew well in maize agar medium compared to potato dextrose agar medium. With regard to phenotypic characters of mycelia on the culture medium, mycelial growth of $P$. florida appeared thick, cottony white and rhizomorphic strands as generally noticed in most of the mushroom culture. Interestingly, $P$. djamor isolate woody 1 appeared thin, loosely grown, non-rhizomorphic mycelia and sparingly aggregated white mycelial strands. $P$. djamor isolate virutha appeared intermediate mycelial type such as moderately rhizomorphic mycelial aggregation and moderately thick and white growth. With regard to mycelia growth pattern on the spawn, $P$. djamor isolate woody1 and $P$. djamor isolate virutha 1 appeared loosely interwoven, low mycelial density and non-rhizomorphic mycelial strands on the paddy/sorghum grain substrates. Whereas, $P$. florida appeared thick, densely grown, cottony white and rhizomorphic mycelial strands on the paddy/sorghum grain substrates. The appearance of the thin/loose filamentous mycelial pattern can be used as phenotypic marker for the identification of these two new $P$. djamor isolates woody1 and $P$. djamor isolate virutha 1 .

\section{Introduction}

Oyster mushrooms (Pleurotus spp.) are suitable for commercial cultivation throughout the years in subtropical regions and winter seasons in tropical regions of the world. They grow naturally on dead and decaying but un-decomposed wooden logs and on dying trunks of wood trees in the temperate and tropical region. The oyster mushrooms have two distinct parts such as oyster like fleshy shell or cap (pileus), a short or long lateral stalk known as stipe. Beneath the pileus, long ridges and furrows known as gills or lamellae are present.

Basidiocarps of oyster mushroom are praised for culinary purpose since they are rich in protein, fiber, vitamins (rich in vitamin B) and minerals (rich in potassium) (Chang and 
Miles, 2004; Reis et al., 2012). In addition to their nutritional value, these fungi produce vital and medicinally important biomolecules (Papaspyridi, 2011).

Mushroom mycelial growth is influenced by culture media, type of substrates and temperature and for basidiocarp production relative humidity plays important role in addition of type of substrates and temperature. Cereal grain based media are best suited for the culturing of oyster mushroom (Rajoriya and Gupta, 2015).

Temperature is the most important conditions for the mycelial growth and basidiocarp formation. Oyster mushroom requires $28^{\circ} \mathrm{C}$ for optimum growth (Wasantha Kumar and Edirimanna, 2009; Nwokoye et al., 2010; Hoa and Wang, 2015). However, for basidiocarp formation, it requires $22-25^{\circ} \mathrm{C}$ with high relative humidity more than $80 \%$.

Thus growing of oyster mushroom is restricted to the winter months especially between October and February in India. Cropping period of oyster mushroom is 50 days.

In order to develop germplasms of oyster mushroom with great genetic diversity, earlier we started natural collection of several Pleurotus spp. and identified two isolates viz., $P$. djamor isolate woody 1 and $P$. djamor isolate virutha1 (Viruthambigai, 2019). Typically, both Pleurous sp. isolate virutha and $P$. djamor isolate woody 1 has no stipe (astipitate). Whereas $P$. florida had well developed stipe. Basidiocarp of $P$. djamor isolate woody 1 appeared as white whereas that of $P$. djamor isolate virutha appeared light pink in colour at primordial phase and later the color changes to white. P. florida appeared in creamy white in colour. Thus, in the present study, the mycelial growth pattern of the newly identified Pleurotus spp. were analysed and found that the mycelia of $P$. djamor isolate woody1 typically appeared non-rhizomorphic, thin and loosely arranged mycelial strands both on the culture medium and in the spawn

\section{Materials and Methods}

\section{Isolation and culturing of Pleurotus spp}

Healthy and fully matured basidiocarp was collected and surface sterilized with $70 \%$ ethanol. The basidiocarp was longitudinally split open into two halves using new sterile blade. A small piece of plectenchymetous tissue was taken from the centre portion of the split mushroom at the junction point of the pileus and stipe.

Three tissue bits were placed on the PDA medium blended with $100 \mathrm{ppm}$ of streptomycin sulphate in the Petri plates at equal-distance and incubated at $28^{\circ} \mathrm{C}$ until the medium was fully covered with mycelial growth. The pure culture of Pleurotus spp. was maintained on PDA slants for further use during this study. Three Pleurotus spp. viz., $P$. florida, $P$. djamor isolate virutha 1 and $P$. djamor isolate woody 1 were used in this study.

\section{Mycelial growth phenotype on culture media}

To study the mycelial phenotypic characters of Pleurotus sp., five millimetre culture discs were cut with sterilized cork borer from advancing margins of the colonies and inoculated on PDA and maize agar medium supplemented with streptomycin sulphate (100 ppm). The plates were incubated at $28^{\circ} \mathrm{C}$. Five replications were maintained for each medium. Radial growth of the mycelium was recorded when the mycelial growth covered in any one of medium. Mycelial characters were observed visually. 
Spawn running period and pattern of mycelial growth on the spawn substrate

The well grown mycelia of $P$. florida, $P$. djamor isolate virutha 1 and $P$. djamor isolate woody 1 were used for preparing spawn. For the preparation of spawn, paddy grains or sorghum grains were used as substrate. Disease free and healthy grains were soaked for 2 hours in water. The excess water was drained and grains were allowed to incubate in wet condition for 12-18 hours.

The well soaked and incubated grains were boiled for 1 hour and then shade dried. The calcium carbonate was added to the grains at the rate of $20 \mathrm{~g}$ per $\mathrm{kg}$ of seeds for absorbing excess moisture and retaining adequate moisture; maintaining the slightly alkaline conditions and to prevent sticking of grains with one another. The grains were filled upto three-fourths of the height of polypropylene cover. The PVC rings were placed on the top of the grain filled covers and the edges were folded down.

The mouths of the bags were plugged tightly with non-absorbent cotton and autoclavesterilized at $20 \mathrm{lbs}$ for the period of two hours. Mycelial discs of 8 to $10 \mathrm{~mm}$ diameter of pure mycelial culture of Pleurotus species were taken from Petri plate and transferred to the sterilized grains and incubated at $28^{\circ} \mathrm{C}$ for the period of 15 days. The time taken for development of entire spawn and pattern of growth were noted.

\section{Results and Discussion}

Mycelial growth pattern of pleurotus spp. on culture media

Phenotypic characters on the mycelial growth of $P$. florida, $P$. djamor isolate virutha 1 and $P$. djamor isolate woody 1 were studied on PDA and maize agar medium. The maximum mycelial growth for all the three Pleurotus spp. was observed on maize agar medium. With regard to the phenotypic characters, mycelia of $P$. florida appeared thick, cottony white and rhizomorphic strands as generally noticed in most of the mushroom culture.

However, $P$. djamor isolate woody 1 appeared thin, loosely interwoven, nonrhizomorphic mycelia and sparingly aggregated white mycelial strands. $P$. djamor isolate viruthal appeared intermediate mycelial type such as moderately rhizomorphic mycelial aggregation and moderately thick and white growth (Figure 1; Table 1).

Table.1 Phenotypic characters of mycelia of Pleurotus spp. on culture medium and spawn

\begin{tabular}{|l|c|l|l|}
\hline Pleurotus spp & $\begin{array}{c}\text { Days required for } \\
\text { spawn development }\end{array}$ & \multicolumn{2}{|c|}{ Mycelial growth pattern } \\
\cline { 4 - 4 } & $15.6^{\mathrm{b}}$ & $\begin{array}{l}\text { On culture medium } \\
\text { thick white mycelium }\end{array}$ & $\begin{array}{l}\text { In the spawn } \\
\text { thick white mycelium }\end{array}$ \\
\hline $\boldsymbol{P}$. $\boldsymbol{d}$ isolate virutha 1 & $13.6^{\mathrm{a}}$ & $\begin{array}{l}\text { Moderately thick } \\
\text { white mycelium }\end{array}$ & $\begin{array}{l}\text { Thin and sparse } \\
\text { mycelium and non- } \\
\text { rhizomorphic } \\
\text { mycelium }\end{array}$ \\
\hline $\boldsymbol{P}$. isolate woody 1 & $13.0^{\mathrm{a}}$ & $\begin{array}{l}\text { Thin, loose and } \\
\text { sparse mycelium } \\
\text { and,non- } \\
\text { rhizomorphic } \\
\text { mycelium }\end{array}$ & $\begin{array}{l}\text { Thin and sparse } \\
\text { mycelium and non- } \\
\text { rhizomorphic } \\
\text { mycelium }\end{array}$ \\
\hline
\end{tabular}



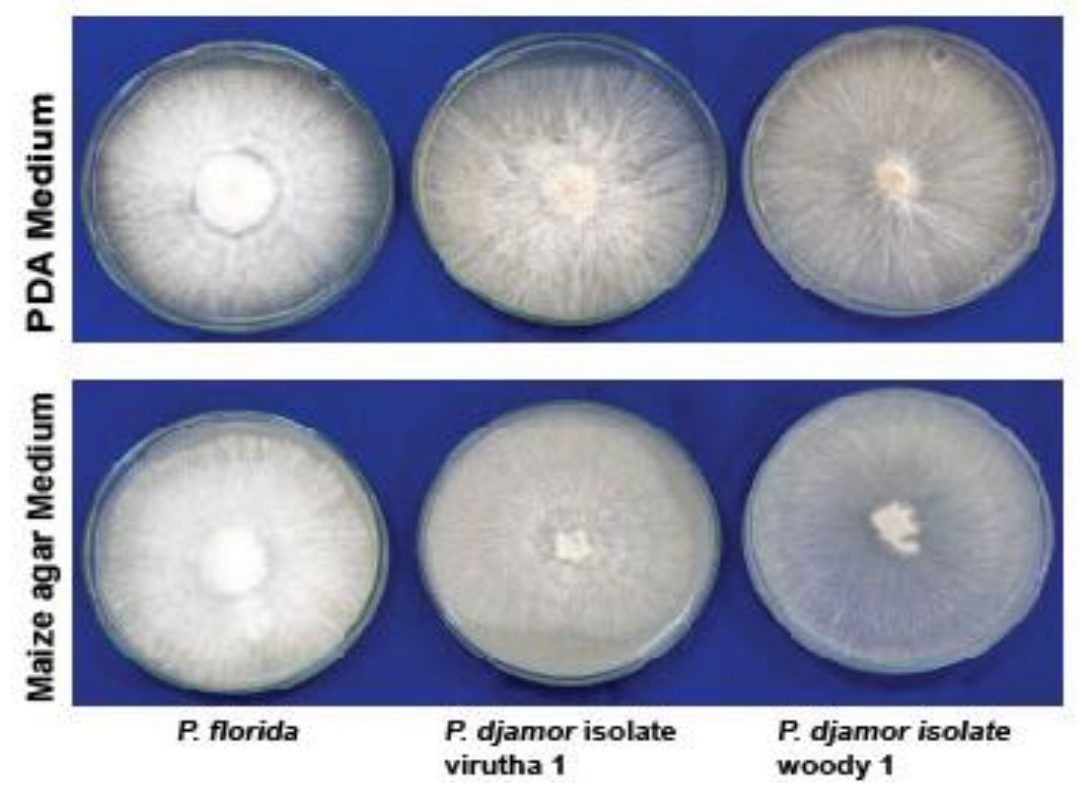

Fig.1 Effect of mycelial growth of different Pleurotus spp on PDA and Maize agar medium

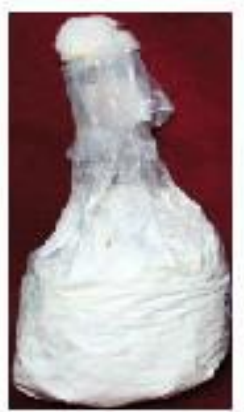

P. florida

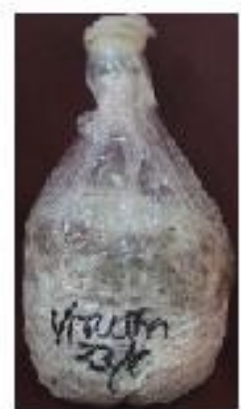

P. djamor isolate virutha 1

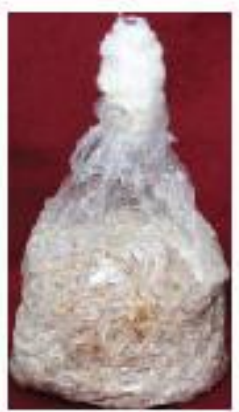

P. djamor isolate woody 1

Fig.2 Mycelial growth pattern of different Pleurotus spp on paddy grains as a spawn substrate

Mycelial growth pattern of different Pleurotus spp. on spawn substrate

P. florida grew as thick compact white mycelium and covers the spawn completely within 15 days on the paddy grains as a substrate for spawn. White mycelia of $P$. florida completely covers the grain substrate used in the spawn and the grains in the bags are not visible.

Whereas $P$. djamor isolate virutha 1 and $P$. djamor isolate woody 1 appears thin, loosely interwoven and non-rhizomorphic mycelia and complete mycelial growth occurred in 13 days (Figure.2; Table.1). Since, the mycelia of both the new isolates appeared thin filamentous strands instead of thick, cottony white mycelium in other mushroom cultures, this mycelial morphological characters can be used as a phenotypic marker for identification of the $P$. djamor isolate woody 1 and also can be used in breeding program to analyse the segregation patterns and progenies.

\section{References}

Chang ST, Miles PG. Mushrooms: Cultivation, nutritional value, medicinal effect and environmental impact. CRS Press 2004;

Hoa, H. T. and Wang, C.L. The effects of 
temperature and nutritional conditions on mycelial growth of two oyster mushrooms (Pleurotus ostreatus and Pleurotus cystidiosus). Journal of Microbiology, 2015; 43 (1):14-23.

Nwokoye, A.I., Kuforiji, O.O. and Oni, P.I. 2010. Studies on mycelial growth requirements of Pleurotus ostreatus (Fr.) Singer. International journal of basic and applied science. 2010; 10 (2):47-53.

Papaspyridi LM, Aligiannis N, Christakopoulos P, Skaltsounis L, Fokialakis N. Production of bioactive metabolites with pharmaceutical and nutraceutical interest by submerged fermentation of Pleurotus ostreatus in a batch stirred tank bioreactor. Proc Food Sci 2011; 1:1746-1752.
Reis FS, Barros L, Martins A, Ferreira I. Chemical composition and nutritional value of the most widely appreciated cultivated mushrooms. An interspecies comparative study. Food Chem Toxicol 2012; 50:191-197.

Viruthambigai S, Kannan R, Arumugam Pillai M, Ramamoorthy V, Reihana, R and VK Parthiban. Studies on morphological and growth characters of new Pleurotus isolates. Journal of Pharmacognosy and Phytochemistry 2019; 8(3): 3328-3330.

Wasantha kumar KL, Edirimanna ICS. Improvement of strains of two oyster mushroom cultivars using duel culture technique. World Applied Sciences Journal 2009; 7 (5): 654-660.

\section{How to cite this article:}

Samundeeswari. S., S. Viruthambigai, R. Kannan, K. G. Sabarinathan and Ramamoorthy. V. 2020. Characteristic Mycelial Phenotype of New Pleurotus spp. used as a Marker for Identification. Int.J.Curr.Microbiol.App.Sci. 9(07): 557-561. doi: https://doi.org/10.20546/ijcmas.2020.907.062 